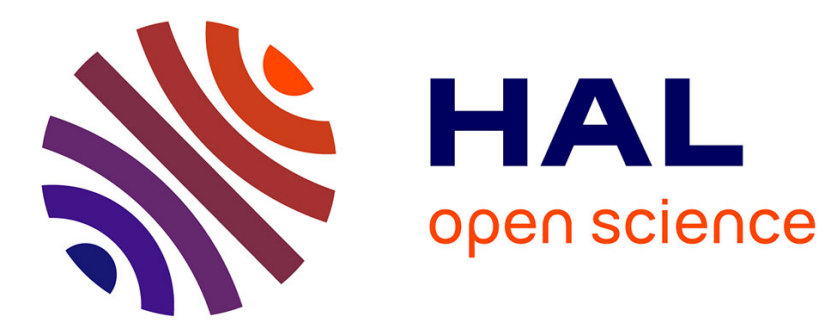

\title{
The Bishop and the law, according to Hincmar's Life of Saint Remigius \\ Marie-Céline Isaïa
}

\section{To cite this version:}

Marie-Céline Isaïa. The Bishop and the law, according to Hincmar's Life of Saint Remigius. Rachel Stone; Charles West. Hincmar of Rheims. Life and Work, Manchester University Press, pp.170-189, 2015, 978-0-7190-9140-7. hal-01644793

\section{HAL Id: hal-01644793 https://hal.science/hal-01644793}

Submitted on 22 Nov 2017

HAL is a multi-disciplinary open access archive for the deposit and dissemination of scientific research documents, whether they are published or not. The documents may come from teaching and research institutions in France or abroad, or from public or private research centers.
L'archive ouverte pluridisciplinaire HAL, est destinée au dépôt et à la diffusion de documents scientifiques de niveau recherche, publiés ou non, émanant des établissements d'enseignement et de recherche français ou étrangers, des laboratoires publics ou privés. 


\title{
D'après une communication présentée à Leeds en juillet 2012, dans les sessions réunies par Rachel Stone et Charles West, chapitre publié comme
}

\author{
Marie-Céline Isaïa, "The Bishop and the law, according to Hincmar's Life of Saint \\ Remigius ", Hincmar. Life and Works, dir. R. Stone and Ch. West, Manchester, Manchester \\ University Press, 2015, p. 170-189.
}

Among the works of Hincmar of Rheims, the Vita sancti Remigii ${ }^{1}$ continues to be regarded as a minor text, a little folkloric recreation that the archbishop permitted himself in old age. ${ }^{2}$ Written after his most serious theological and political treatises, the Life of Saint Remigius has been seen as a motley compilation, accumulating traditions, or inventing them, about a relatively obscure Merovingian bishop. Certainly Saint Remigius, who died around 533/535, did not enjoy a very widespread cult when Hincmar began his work. An extremely short, anonymous and archaic Vita Remedii credited the saint with the merit of having resurrected a dead man - but it is a work of slight importance, compared to the Vitae of other glories of the Gallic sanctoral, such as Germanus of Auxerre. ${ }^{3}$ Hincmar toiled to learn more, but in vain, as he recalls in his preface addressed to SaintRemi's monks : the older ones remembered that their predecessors "had seen a very great book, written in an antique script, that recounted Remigius's birth, life, virtues and death... but it had been destroyed... You rightfully wished that I should gather these scattered elements in a single œuvre... I would have achieved this a long time ago, if I had not been delayed by a vain hope: I heard, from here and there, that I might succeed in retrieving the great book about the virtues and life of our lord and patron saint;... all was but lies". ${ }^{4}$ So Hincmar filled the gaps as he could.

It would however be unfair to see nothing in this hagiographical text but a work of the imagination, isolated from the whole œuvre of Hincmar. The Vita is clearly entirely coherent with his political thought - a coherence that for Bruno Krusch proved it had been written ad hoc, that is to say that it tells nothing but a (forged) truth that served Hincmar. ${ }^{5}$ De facto, the Vita attests to and

1 Hincmarus Remensis, Vita sancti Remigii archiepiscopi Remensis, Bibliotheca Hagiographica Latina [BHL] 71527164, ed. B. KRUSCH, Monumenta Germaniae historica [MGH], Scriptores Rerum Merovingicarum, III, Hannover, 1896, p. 250-341. The Vita is referenced as follows: $V R$ chapter, page, line.

2 This is notably the opinion of Jean Devisse in Hincmar, archevêque de Reims (845-882), Genève, Droz, $1975-1976$. Hincmarus Remensis, Vita sancti Remigii archiepiscopi Remensis, Bibliotheca Hagiographica Latina [BHL] 71527164, ed. B. KRUSCH, Monumenta Germaniae historica [MGH], Scriptores Rerum Merovingicarum, III, Hannover, 1896, p. 250-341. The Vita is referenced as follows: VR chapter, page, line. For a recent presentation of the Vita, also see M.-C. ISAÏA, Remi de Reims. Histoire d'un saint, mémoire d'une Église, Paris, 2010, p. 465-546.

3 Venantius Fortunatus (Pseudo), Vita sancti Remedii, BHL 7150, ed. B. KRUSCH, MGH, Auctores antiquissimi, IV, 2 , Berlin, 1885, p. 64-67 ; Remi de Reims, op. cit., pp.373-380.

4 VR preface, 250, 39-41: "eos vidisse librum maxime quantitatis manu antiquaria scriptum de ortu ac vita et virtutibus atque obitu beati Remigii sanctissimi patronis nostri. Qui...deperiit"; 253, 12-16: "Unde bonis vestris desideriis placuit, ut illa mea servitus...in unum colligeret. Quod etiam diu fecissem, nisi me spes vana deluderet, quibusdam dicentibus, quia in illo et illo loco magnum librum de vita et virtutibus ipsius domni et patronis nostri repperire valerem...penitus falsa inveni."

5 Krusch's preface of his edition of the Vita is a tremendous requisitory against Hincmar : "Hincmar.... a man inflated by a huge desire of domination, addicted to a stupendous guile... was very disappointed by the extant Vita brevis, that did not suit his desires... and he took a resolution full of cunning [to prove] that the previous Vita, [that he needed to assert his views], actually existed. But the Vita prolixior that he had forged, if totally destroyed, could not serve him : this is the reason why he though about a rather clever tale..." and further "He wants that we believe that all his assertions come from his papers... but he is the author of all the stories he added to the documents he pretends to quote... Saint Remigius fortunately succeeded in every enterprise that Hincmar failed to achieve ", "homo nimia dominandi cupiditate inflatus miraque astutia praeditus... Brevis quae iam extabat $V$. Remedii eius desideriis minime satisfecit... Homo autem astutus...consilium multae calliditatis iniit. Ut probaret, Vitam eam quam desiderabat re vera extitisse... Prolixior quam finxit Vita, si penitus periisset, proficere ei non potuisset, ideoque fabulam sibi excogitavit satis ingeniosam", pp. 239, 2-240, 7, and "Haec igitur ex schedulis suis pendere credi voluit... atque omnia, quae documentis notis addidit Hincmarus, ficta sunt... Sanctus igitur ea bono eventu perfecerat, quae sine successu susceperat Hincmarus...", p. 241, 20-21 and 43 . 
spreads the legend of the Holy Ampulla, in the same years as this object became useful for the coronation of Charles the Bald as king of Lotharingia (869). ${ }^{6}$ Historians recognized a long time ago that the Vita exposes, with its own words, Hincmar's theory about contractual monarchy and warns Carolingian kings against the temptation to hijack the Church's property. ${ }^{7}$ Moreover, the more one explores its composition, the more one realises that Hincmar conceived his Vita as a kind of library capable of holding the quintessentials of his theological and pastoral beliefs: intermingled with saint Remigius's biographical outline, more theoretical developments on predestination or the Trinity directly reflect Hincmar's teachings on these subjects. ${ }^{8}$ Furthermore, Hincmar evidently began to write the Vita before 852, even if only his death in 882 prevented him from supplementing it again and again: one must conclude that the Vita Remigii is not (only) the testament of Hincmar, but (also) the founding text of his episcopacy ${ }^{9}{ }^{10}$ Hincmar wanted it to be a constantly enhanced text of selfjustification that could warrant all his deeds, from his promotion at Rheims against Ebbo's rights (845) to his actions as kings' counsellor: its main meaning is that the authority of the archbishop of Rheims should not be challenged, since it is based on the precedent of Remigius of Rheims, the greatest apostle that Francia ever had.

\section{The normative effects of a hagiographical text}

Hincmar's project followed a long tradition that led him to believe that his Vita would contribute to the religious progress of its readers. So he constructed his Vita as a dialogue between past and present, between the $6^{\text {th }}$ century of Remigius and his $9^{\text {th }}$ century, for a moral purpose. After describing some deed of saint Remigius, Hincmar draws a lesson addressed to all his contemporaries, especially Carolingian bishops, monks and kings. This is why of all his own works he cited in the Vita, it is his moral treaty, "The sins one should avoid and the virtues one should cultivate", De cavendis vitiis et virtutibus exercendis, on which he drew most often ${ }^{11}$ : Hincmar quotes this work on at least eighteen occasions, because the Vita is the means Hincmar created to exhort his audience to moral and religous improvement. ${ }^{12}$ So the Vita tends towards being a speculum, exactly as the De cavendis is a moral guide for King Charles the Bald, and Hincmar reuses in both useful patristic formulas he found. When for example Remigius had dinner at home, as Hincmar tells us following the Vita Remedii, he distributed his leftovers to birds, who ate out of his hand. "We can receive an excellent moral lesson considering this action of saint Remigius" 13 continues Hincmar: we can rejuvenate by prayer, by studying, by regretting our sins, even if our flesh grows older. ${ }^{14} \mathrm{He}$ does not admit that this is a teaching of Pope Gregory the Great $^{15}$, that he had already used in the De cavendis. ${ }^{16}$

It was not unusual to assign a moral aim to a hagiographical text, which, as many Merovingian Vitae repeat, should contribute to the edification of each of the fideles who hears it read. This is the normal parenetic or hortatory function of hagiography. The only remarkable thing here is the systematic and explicit moral lesson: Hincmar explains in what sense we must interpret

6 VR c. $15,296,31-297,4$.

7 VR c. $14,296,1-15$.

8 See below. Some important teachings can be read in VR c. 8, 281-284 on predestination and in VR c.7, 275 about the right understanding of the dogma of the Trinity.

9

10 M.-C. ISAÏA, Remi de Reims, op. cit. p. 528-529.

11 De cavendis vitiis et virtutibus exercendis, ed. D. Nachtmann, MGH, Quellen zur Geistgeschichte des Mittelalters 16, Munich, 1998.

12 B. Krusch did not note the presence of the De cavendis inside the Vita Remigii, so there may be more quotations than the 18 important ones I have noticed. Even so, I believe that the De cavendis is the most important Hincmarian source of the Vita.

13 VR c. 5, 268, 19-21:. "Sic et de hoc beati Remigii facto maximam instructionis aedificationem...valemus assumere." VR 268, 19-21.

14 VR c. $5,268,38-269,3$.

15 Gregorius Magnus, Moralia in Job, XIX, 30, 53, ed. M. Adriaen, Corpus christianorum Series Latina 143B, Turnhout, 1985, p. 999, 1. 15-22.

16 De cavendis II, 3, ed. D. Nachtmann 180, 13-19. 
the story he tells, he does not let the reader draw his own conclusions. For instance, in chapter 17, Remigius saves a certain Eulogius, who was accused of treason: thanks to the intercession of the bishop, Eulogius was not sentenced to death by King Clovis, and even his villa of Epernay was not confiscated. Eulogius wanted to thank the bishop by giving him the villa, but Remigius refused the gift and bought it instead. Hincmar comments:

This is a good example that Remigius left all bishops, both his contemporaries in the flesh and those who will come after him in the priesthood: when they help the poor, widows, orphans and all those who seek the refuge of the Church and of their mercy, those who have been wronged, or are condemned to exile or banishment because of their sins, or who are within the scope of any judgment - when they bring them any kind of relief, they should not receive temporal reward in exchange. But, according to the word of the Lord 'Freely you received, freely give' [Matthew 10,8] they must give generously what they have received by the grace of God to those around them, that is what they were given freely - freely indeed meaning without awaiting temporal counterpart. ${ }^{17}$ ",

From a human experience that provides an exemplum, and from a saying from the Scriptures, Hincmar generalizes: this is the most common homiletical method. The originality of the Vita Remigii lies elsewhere, in the definition of the episcopal office it assumes. When adopting a homiletic tone, like many other Vitae, it immediately justifies this method by portraying the bishop of Rheims as a master whose examples and teachings must be followed step by step. Hincmar actually blurs the difference between the actions of Remigius on one hand and his own commentaries on the other, assuming that there is a perfect, mystical continuity between them. The Vita thereby offers a complete portrait of what Hincmar thinks that a Carolingian bishop must be, a man whose responsibility is to tell others what they have to do. Now this does not only imply a moral standpoint: Hincmar extends the clerical responsibility of teaching to a much broader normative authority. As the example of Eulogius shows, he does not merely tell good from evil, but also defines what is fair, legitimate and permitted. Hence, the Vita Remigii must be seen as the very core of Hincmar's œuvre: the man who spends his life telling others what they should do or say or believe, chose hagiography to teach dogmatic and theological truths, to impose rules and to reinforce his normative power.

Of course, the Life of St. Remigius cannot be reduced simply to a series of legal articles: Hincmar also composed his Vita to give the episcopal Church of Rheims a history, to justify the monastic community of Saint-Remi's heavy dependence on the successor of Remigius as bishop, to exalt the memory of the saint who baptized Clovis and who introduced the Franks into the history of salvation. It seems nevertheless possible to say that Hincmar conceived his Vita both as a historical and a normative text; or as a normative text because it is primarily about the past, a christianized and heavily rewritten past. Nowadays, what we call rules are straightforward, unambiguous texts that set norms, requirements, laws of general scope: these texts are objective ones, or supposed to be, written in the present. Hagiographical texts are exactly the opposite: stories, series of anecdotes, narratives of events, with witnesses, main characters and secondary ones, a biographical logic, sometimes with plots or twists, all necessarily presented in the past and, by definition, not of general scope since it is always the history of an individual, a particular case. Meetings between the two genres, however, may have been more numerous during the early Middle Ages: their first common point is that both the rules and the Vitae are supported by a community and a common acknowledgment of a shared past. This is the community that provides the

17 VR c. 17, 309, 2-10: "bonum exemplum omnibus episcopis, tam suo tempore in carne viventibus, quam post eum in ordine succedentibus, derelinquens, ut pauperibus aut viduis vel pupillis vel pro his qui ad misericordiam aecclesiae confugiunt, qui iniuriam patiuntur, aut qui peccantes in exilio vel in insulis damnantur, aut certe quamcumque sententiam suscipiunt, iuxta sacros canones subvenientes, vel quaecumque agentes bona pro temporali retributione non faciant; sed iuxta vocem dominicam: Gratis accepistis, gratis date, quod Dei gratia, id est gratis data, acceperunt, gratis etiam, id est sine retributione temporali, proximis largiantur." 
inspiration for the customs as for the Vita, by a collective effort of recollection of its past, both of past uses and past events - and it is a community that emerges in the sharing of rules or in the commemoration of its peculiar patron saint. Therefore, Hincmar's choice of hagiography is not totally unexpected. He makes a visible effort to underline that he wrote nothing about Remigius but the story he received from his predecessors. This is not simply the commonplace tune of hagiographical prefaces: the unanimity of the clergy, their participation in collecting and believing the events Hincmar tells about Remigius, is the very foundation on which the archbishop will base his authority. It justifies the entirely unusual importance of a normative discourse within the Vita.

Homiletic moments set apart, the normative strength of the Vita sometimes comes from its capacity to include evidence seized elsewhere and embedded in the text, as in the case of a letter of Pope Hormisdas, an authentic letter (adapted by Hincmar): the archbishop inserted this document as a conspicuous proof that could not be debated. But most of this evidence is slid inside the Vita, sewn into it as secretly as possible. Hincmar 'honestly' announced part of this technique in the preface: he would compose his Vita from different and heterogeneous origins... but he almost never indicates which piece is borrowed, or from whom. The heterogeneity he acknowledges is due, if we believe him, to his desire not to modify the different texts he collected about Remigius. ${ }^{18}$ There is however a more striking heterogeneity, due to the (sometimes awkward) way in which Hincmar put into the Vita words he took from his own previous works. We cannot blame a computer for this frequent copy/paste, so one must understand that Hincmar collected in his treatises the theological convictions he thought most precious, to disseminate them again to a larger audience. In the table of contents Hincmar included in the begining of the Vita, he explicitly states that episodes from the life of Remigius will be accompanied by lessons. For example, chapter 8 announces a long speech about predestination, and the heresy of those who misunderstand it:

Chapter 8 : How he [saint Remigius] rescued the city of Rheims from the fire, this city that the devil had set alight, and how we shall also be rescued by the means of his merits and prayers, if we ask without weakening, by releasing us from the vices and flames of eternal fire. Hence, by comparison, the brief summary of the error of the heretics, who claim that God has predestined some men to eternal fire, and, conversely, the demonstration of the truth of the Catholic faith". ${ }^{19}$

We must conclude that there are three steps in the Vita: the narrative of the facts (Remigius stopped the burning of the city of Rheims), their spiritual understanding (Remigius can fight against our vices), but also their dogmatic interpretation (what is to be believed for one's salvation). Hincmar improves the technique of the sermon, constructing his text on the various senses of Scriptures, literal, moral and anagogical, and playing on similarities, sumpta similitudine, here on the word "fire", that can be real fire, spiritual or eschatological. This is noteworthy in a hagiographical text: the shift from the historical narrative to the admonition is common, but not to this degree, and the third meaning is never or rarely developed so insistently. In chapter 8, there are 30 lines on the "real" fire, and 215 lines of theological teaching. Why is Hincmar so talkative on the subject? Because his teaching on heresy and its refutation is to be found, in a different order, in his treaty on

18 VR preface, 253, 26-28: "In the following pages, let the reader not be disturbed by the diversity of style : I put, exactly as I found them, the facts I received from the histories of our ancestors, and those I noticed in old parchments." 19 VR table of contents, 255, 7-12: "Qualiter civitatem Remorum conflagratam per demonem ab incendio liberavit, et nos, si fideliter petierimus, eius meritis et orationibus a viciorum flammis et ab igne perpetuo liberari valebimus. Unde, sumpta similitudine, commemorata est breviter falsitas predestinatianorum hereticorum, qui dicunt, Deum quosdam ad ignem perpetuum predestinasse; et hinc catholicae fidei veritas demonstratur." 
the same topic, De praedestinatione..$^{20}$ In a way, Hincmar summarised his treatise for popularisation through the Vita Remigii.

The Vita admonishes kings as a Speculum does $^{21}$; the Vita publicises truths a Christian must understand; the Vita gives Rheims the past it must have to legitimate its domination of political intrigues. All these achievements are possible because, above all, the Vita states that a bishop is a law-giver, and the very source of every catholic -that is universal - norm. Anyone who thinks of Hincmar as conservative will be surprised to discover him claiming, sotto voce, complete freedom for bishops in creating the norms the Vita promotes; even if he presents the council as an opportune moment for this creation, he does not assert that the definition of norms is a collective action. Indeed, Hincmar's Vita appears to represent the moment when Latin hagiography attempts to become a medium for norms rather than an edifying discourse; though perhaps a brief apogée, rather than a successful and durable begining.

\section{The bishop as a law-giver}

One of the major innovations of Hincmar's Saint Remigius is his alleged involvement in councils. A brief and positivist look at the saint's episcopacy must conclude that there is no sign that Remigius attended any known council in Gaul from 458 to 535, and especially not the exceptional council of Orléans which Clovis organized in $511 .^{22} \mathrm{He}$ did not call for provincial meetings either, not even the simplest diocesan synod, during more than fifty years. This lacuna did not fit new Carolingian norms, a problem which Hincmar solved in a very subtle way. In the Vita's chapter 20, he inserted a letter written by Pope Hormisdas. ${ }^{23}$ It is well-known since Krusch's work, followed by Devisse, that the archbishop based his own claims to be a kind of papal vicar for the kingdom on this (forged) letter, as he asserts for himself the privileges Hormisdas is said to have accorded to Remigius. ${ }^{24}$ This letter sums up in a theoretical way what the bishop's mission must be: it is not christianization, nor the spiritual life, the correct celebration of the sacraments or the defense of the faith against heresy, it is the observance of rules. More precisely, preaching the faith and constructing the Church may be summarised in a single expression, that is keeping the tradition expressed in canonical law and confirmed by papal authority. In his letter, Pope Hormisdas begins by rejoicing in the election of Remigius as a bishop: "So we received by anticipation an omen that our choice [of Remigius as the papal vicar] is judicious, when we learned that you have accomplished what we order in all humility to all others to do, that is to say that you try to maintain the observance of the rule of the fathers and the authority of the apostolic See in regions whose unity is threatened by such a removal ${ }^{25}$." Then the Pope makes Remigius his vicar, congratulates him on the baptism of the Franks, and continues with exhortations on the mission of a bishop, that is mainly to maintain the canons:

20 Hincmarus Remensis, De Praedestinatione Dei et liberio arbitrio dissertatio posterior, Patrologia Latina 125, c. 65474. One can notice at least these repetitions, VR 281, 14-15= De Praed., col. 421 ; VR 281, 33-35=De Praed., col. $190=$ Grég., Hom. Ez. I, 9, 42 ; VR 283, 22-26 and 28-30 = De Praed., col. 444 ; VR 283, 37-39= De Praed., col. 82 ; VR 283, 42-284, 1-12 = Pope Leo the Great, Tractatus septem et nonaginta, ed. A. Chavasse, CCSL 138, Turnhout, 1973, n LXII, c. 351-352 with VR 283, 42-45 = De Praed., col. 345 ; VR 284, 22-27 = De Praed., col. 368 ; VR 284 , 27-29 = De Praed., col. 288 ; VR 284, 29-30 looks like De Praed., col. 283 ; VR 284, 30-32= De Praed., multi loci= Pope Leo the Great, Epistola CLXV, c. 1161 ; VR 284, 34-37 = De Praed., col. 307.

21 I suspect that a first version of the Vita was addressed to Louis the German, as a sort of monition: see Remi de Reims, op. cit. p. 523.

22 We still need a fresh look on Orléans' council of 511, that cannot be reduced to the beginning of a secular and French alliance between the throne and the altar. Gregory Halfond began to answer this need, first in his Archaeology of Frankish Church Councils, AD 511-768, Leiden/Boston, Brill, 2010, then in his paper "Vouillé, Orléans (511) and the Origins of the Frankish Conciliar Tradition", The Battle of Vouillé, 507 CE. Where France Began, ed. R. W. Mathisen and D. Shanzer, Boston/Belrin, Wlater de Gruyter, 2012, pp. 151-166.

23 VR 311, 31-313, 20, especially 3111, 34-312, 30.

24 Br. KRUSCH, Vita Remigii, pp. 241-242 and J. DeVISSE, Hincmar, op. cit., p. 652.

25 VR c. 20, 312, 8-11: "Praerogativam igitur de nostri sumpsimus electione iudicii, quando id operatum te esse didicimus, quod ceteris agendum obnixius imperamus, ut in provinciis tanta longinquitate disiunctis et apostolicae sedis vigorem et patrum regulis studeas adhibere custodiam" 
Thus we give the order that the rules and prescriptions of the Fathers that the most holy councils have defined may be observed by all. Your vigilance on these matters, your concern about these cases, we underline them with our fraternal exhortations. How well it is that you are so respectful a keeper of these laws that no single opportunity of fault remains, nor obstacle to the holy observance! This is where we find specified what is lawful and what is unlawful, written what is forbidden and after what no one should have the audacity to aspire, there what is allowed, and that a mind should seek to please $\mathrm{God}^{26}$.

The bishop is thus defined by the authentic letter of Hormisdas as a custodian of the canonical law, as it summarised the Roman Church tradition: no wonder that the pope insists on this point, because he writes to a bishop of Spain under Visigothic domination ${ }^{27}$. But Hincmar selected this letter, and no other, to forge a brief correspondance between Rheims and Rome: and it is not only a question of contemporaneity, even if Hincmar relies on the fact that Hormisdas and Remigius could have exchanged letters. The letter fits both Hincmar's desire and practice to reinforce the normative power of the archbishops, as sustained by papal authority. The letter goes further : it underlines "Remigius"'s responsibility in maintaining Church tradition, but also his ability to exert normative power over the clergy of his diocese, by the mean of the council: "Whenever the defense of religion demands a general council, all your brothers should gather on your summons, and if a particular topic is the occasion of trouble between some of them, then restrain disputes born between them, and find solutions to conflicts by examining the holy Law [the Scriptures, lex sacra] ${ }^{28}$." With such a definition of episcopal ministry, one should not be surprised if, in the Vita, Remigius's voice and that of Hincmar combine to formulate real rules and not only encouragement or exhortation. The bishop is a legislator, thanks to his knowledge of Scriptures, patristic tradition and canonical law. ${ }^{29}$

What is the more important: to maintain the observance of canon law or to be able to interpret it? Hormisdas openly chose observance, but Hincmar insists on the archbishop's autonomy and ability to create new rules from old ones. Hence, in my opinion, his relatively restrained use of the figure of Moses in the Vita Remigii. In the Vita, Remigius is compared to many great male figures of Old and New Testament, including archangels, kings, prophets and apostles. ${ }^{30}$ Moses appears in the list, but not at its top, and is mentioned for a fact that probably is not the major one of his life: Moses is described not as the one who received the Law, nor the lawgiver, but as the man whose face was radiant:

We read this fact about Moses: his face became radiant when the Lord looked upon him. We hear the same about Remigius, who was glorified by a radiant light. That means that Moses was ordained by God to be a legislator for the people of the Old Testament exactly as the blessed Remigius emerged as the man chosen, by the gift of Christ, to be the steward of the

26 VR c. 20, 312, 19-24: "Paternas igitur regulas et decreta sanctissimis diffinita conciliis ab omnibus servanda mandamus. In his vigilantiam tuam, in his curam, fraternae monita exortationis ostendimus. His ea quanta dignum est reverentia custoditis, nullum relinquit culpae locum sanctae observationis obstaculum . Ibi fas nefasque prescriptum est, ibi prohibitum, ad quod nullus audeat adspirare, ibi concessum, quid debeat mens Deo placitura presumere.

27 For the context of the correspondance between Hormisdas and Salluste, bishop of Seville, see Th. Deswarte, Une chrétienté romaine sans pape. L'Espagne et Rome (586-1085), Paris, 2010. [Page numbers?]

28 VR c. 20, 312, 24-26: "Quotiens universale poscit religionis causa concilium, te cuncti fratres evocante conveniant; et si quos eorum spetialis negocii pulsat intentio, iurgia inter eos oborta compesce discussa sacra lege determinando certamina."

29 On the growing importance of the knowledge of law in the episcopal ministry during Hincmar's career, see L. Jégou, L'évêque, juge de paix (VIII ${ }^{e} X I^{e}$ siècle), Turnhout, 2011 and, more precisely about Hincmar, my "Être historien au $\mathrm{IX}^{\mathrm{e}}$ siècle», Rerum gestarum scritor. Mélanges Sot, ed. M. Coumert, K. Krönert, M.-C. Isaïa and S. Shimahara, Paris, 2012, p. 67-76.

30 See Vita chapter 30 for a good summary of the figures Hincmar used : VR 326, 24-328, 5. Archangels and other types of angels are to be found in the beginning of the very rhetorical chapter 31, VR 328, 6-331, 11, that heavily depends on Gregory the Great's Homelium in Evangelia 34. 
grace of the gospel to the people that had to be renewed in the baptismal font ${ }^{31}$.

Here Hincmar prefers to oppose the age of Law and the age of Grace rather than insist on the continuity between the two legislators - perhaps because he thinks that a Carolingian bishop does not have to deliver a Law he did not write, but to write laws that had not been transmitted to him.

The council therefore is the place where a bishop is able to reinforce his effective authority over other clergy and his intellectual authority by the commemoration of canonical law ${ }^{32}$. So it is certainly no coincidence that in chapter 21 , Hincmar imagined a council chaired by Remigius, a chapter he completely invented, without any previous attestation. ${ }^{33}$ This is a council without place or date, because this is not a historical council, but a staging of the normative authority of the bishop. In the episode's conclusion, Hincmar joined a meditation on the law, from the De cavendis and the Moralia, with a quite spectacular miracle. The situation is very plain: Remigius chairs a council which also involved an Arian heretic. The heretic refuses to get up when Remigius arrives, so he is reduced to silence. Actually mute, he recovers only to confess the Catholic faith on the order of Remigius:

The heretic, once proud, now a humble Catholic, confessed the Catholic faith in the Catholic holy and inseparable Trinity and in the Incarnation of Christ and promised to persevere in this faith he had confess. In this way, Saint Remigius, with the power of God, restored the health of soul and body to the man who had lost his soul by his infidelity and was condemned to the loss of his physical voice by his pride, to show unambiguously to all the other priests who were present, as to those who would read this passage or hear it, what to do about those who sin by their perverse opinions about Christ, who by His humanity deigned to become our neighbour and our brother, how to act towards those who sin against Him or against the Church and who disobey, as against those doing penance after confessing their $\operatorname{sins}^{34}$.

The whole commentary is important, because it is not a mere question of spiritual guidance, a problem of edification of any Christian. From the example of Remigius, Hincmar asks all the priests to behave in a certain way, or rather imposes a norm, since the duty to forgive sins is addressed to a social or professional category, here the clergy. The incentive to forgive does not depend on the personal behaviour of one priest or another: it is the Archbishop of Rheims - that means Remigius as much as Hincmar - who speaks, as he would in a provincial council, and gives a rule to all the clergy of his diocese. Indeed, this discourse of Hincmar is staged on the occasion of a theoretical or ideal type council, in which the roles of Hincmar and Remigius are inseparable: there is the example of Remigius on one side, who is able to convince those who attended the scene, then the extension of the work of Remigius by Hincmar, though other means of communication. This is a

31 VR c. 14, 296, 13-20: "Quod de Moyse scriptum legimus, quia splendida facta est facies eius, dum respiceret in eum Dominus, hoc et in beatum Remigium luce splendida illustratum factum fuisse audimus; quoniam, sicut Moyses legislator populo veteri erat a Domino constitutus, ita et beatus Remigius euvangelicae gratie lator populo in proximo per fontem baptismatis innovando extitit munere Christi electus."

32 About the importance of councils as social experiences and occasions for the creation of a self-conscious representation of the Carolingian episcopate, see especially St. Patzold, Episcopus. Wissen über Bischöfe im Frankenreich des späten 8. bis frühen 10. Jahrhunderts, Ostfildern, 2008.

33 VR 313, 21-314, 10.

34 VR c. 21, 314, 7-16: "ante superbus hereticus, humilis iam et catholicus catholicam fidem de sancta et inseparabili Trinitate et de Christi incarnatione catholice confessus est et in eadem confessionis sue fide se permansurum professus est. Sicque anima per infidelitatem perdito et corporali voce propter superbiam condempnato virtute divina sanctus Remigius et animae et corporis reddidit sanitatem, cunctis qui aderant vel lecturi seu haec audituri erant sacerdotibus patenter ostendens de male sentiendo peccante in Christum, qui per humanitatem proximus et frater nobis fieri dignatus est, quomodo erga peccantes in se vel in aecclesiam atque rebelies et erga post recognoscentes et paenitentes debeant agere." 
first response, very clear, to the question of the transmission of norms: as he explained himself, Hincmar hoped that the hagiographical text will be very widespread, read in public, pondered upon in private; a Life of Saint Remigius is awaited and will circulate throughout the province, so it is a very important medium for the dissemination of rules. It is because of the Vita's anticipated wide dissemination that Hincmar chose to mingle more theoretical lessons with the events of the life of Remigius, as he explains in his preface:

I shall take care to add passages from the words of the Fathers to the admonition of those who read or listen, to passages that describe the miracles that the Lord made by our patron saint ; and to the extent of my understanding, I shall try to walk in the footsteps of the blessed Gregory, although I can not equal him, who, while he described the actions of the saints and the fall of the wicked, drew out an admonition, according to the wisdom that God had communicated to him, and who inserted in his narrative many necessary and useful considerations to those who read them or listen to them ${ }^{35}$.

Hincmar warns us that he will pass from the action of Remigius to exhortations "for those who read or listen". In chapter 21, about the speechless heretic, it is Remigius himself who teaches "to all the other priests who were present, as to those who would read this passage or hear it" ; we understand that Hincmar and Remigius are pretty much interchangeable.

The rule that is expressed here -every penitent must be reconciled-is a recurrent matter for Hincmar. What is worth noticing is that he does not justify it by canons, but by the Law, contained in the Scriptures on the one hand, and by the history of Remigius that embodies justice on the other. Hincmar succeeds in converting a personal belief into an objective norm by the peculiar staging the Vita authorizes, through an alliance of lived example and imperative discourse. Yet that does not totally explain why Hincmar does not quote any canon on this matter. It is only in his table of contents, on chapter 16 , that he alludes to canonical law and promises he will devote time to a canonical explanation about the bishop of Laon, Genebaud: "How one should understand the canonical statement that specifies with extreme insistence that a man subject to penance because of a public sin must not receive ecclesiastical orders or be kept in orders or recover his previous situation $^{36}$." What is chapter 16 about ? A bishop of Laon, Genebaud, had two children with his wife, though they should have separated after his episcopal ordination. Remigius, to whom Genebaud confessed his fault, did not degrade the bishop, but submitted him to a strict penance for seven years before reconciling him. ${ }^{37}$ Hincmar tells the story, then raises the question: did Remigius act in accordance with canonical rules? His answer is a typically Hincmarian one, loudly proclaiming that nothing is more essential that the observance of Church's traditions... before concluding that Remigius was well-inspired not to follow its sacred rules:

No one should be bold enough to enunciate novelties in contradiction with the Apostle, revelling in his own words, by claiming that the sacred rules have been established against this example of God's mercy, or that the blessed Remigius acted in this case with respect to Genebaud against the sacred rules after receiving an order from God, or that it is against the regular canons that Genebaud was kept in his rank after his sin, since the Catholic Fathers proclaimed by mutual agreement this statement which should be sufficient: "When it was established in the Church that no one can receive orders after having done penance for a crime, or re-enter the clergy or remain in the orders,

35 VR preface, 254, 3-9: "In his autem, quae de scriptis virtutum miraculis, a Domino per beatissimum patronum nostrum operatis, ad exortationem legentium sive audientium pro modulo intellectus mei de catholicorum dictis subiungere studebo, vestigia beati Gregorii, licet non valeam, prosequi moliar, qui describens sanctorum actus pravorumque casus, exortatione inde assumpta, secundum sapientiam sibi a Deo datam multa necessaria et utilia legentibus ac audientibus interposuit".

36 VR preface, 256, 21-23: "et qualiter tenenda sit sententia canonum, quae post lapsum publice paenitentem ad gradum ecclesiasticum non accedere vel in gradu manere aut ad gradum redire".

37 VR c. 16, 300, 33-304, 5. On Genebaud, the most important commentary is now in R. Stone, "Gender and Hierarchy : archbishop Hincmar of Rheims (845-882) as a religious man" 
this has not been done due to a lack of confidence in forgiveness, but as a result of rigorous discipline. Otherwise it would challenge the power of the keys given to the Church by these words, 'Whatever you loose will be loosed [Matthew 18;18]'." Nothing is excluded or left out by that 'whatever', meaning 'everything, ${ }^{38}$.

Hincmar concludes this passage with a long though implicit quotation from Augustine.${ }^{39}$ Augustine, and Hincmar after him, finds in the Scriptures the two cases of King David and Peter the apostle, to prove that by true humility, they confessed their sins and obtained not only their pardon, but also maintenance in their functions: David remained king as Peter remained apostle. Moreover, the Vita directly refers to a canonical text that Hincmar wrote himself and which could be found in his Capitula Episcoporum. ${ }^{40}$ This capitulum about the penance of clerics may seem slightly stricter than the Vita, insisting on the necessity of a long penance that teaches humility when the Vita underlines the perfection of the mercy granted - yet there is no deep contradiction between them, only a difference in the form. The gloss Hincmar added in the Vita about the potestas ligandi of the Church aims to guarantee her full freedom of decision. The capitulum had to be drafted by an accumulation of patristic, explicit and traceable evidences or citations, while patristic quotations are invisible and far fewer in the Vita. The important point here is that the hagiographical text comment on the canons: the canons are by definition quite synthesised texts, decisions that do not leave much room for diversity of cases. In the Vita, Hincmar restores the legal interpretation that should accompany the canons. A law should not be used blindly but interpreted, adapted to circumstances. The facts are right against the principles, especially when the historical example is that of a saint. The hagiographic narrative thus serves as an argument of authority to demonstrate that there may be a difference between laws and judgments.

Finally, we obtain an unexpected answer to the question: Why did Hincmar choose to deliver his most intimate convictions and his most crucial commands via a hagiographic text? Speaking about a mere enlargment from the moral improvement assigned to every hagiographical text to a more normative and collective progress is not sufficient. Through hagiography, Hincmar creates two levels of language: on a first level, he composes what appears to be a reminder about canonical rules - on penance, on death, on the organization of a synod - and about dogmatic truths, a reminder which confirms the indisputable authority of the bishop on all these subjects. At the same time, but on another level, Saint Remigius's life demonstrates the total independance of the same bishop vis-à-vis these previous rules. Hincmar illustrates, supports and embodies in concrete behavior the idea he does not want to put explicitly: a bishop of Rheims is the source of law and is little constrained by the rules that constrain others.

\section{Back to a stricter definition of hagiography as history}

Hincmar counted on the diffusion of the Vita, expecting that it would be read in private and in public, broadcast by liturgy and memorized, more effectively than any synodal acts. In this particular regard, Hincmar's expectations failed: as a brief conclusion, a short study of some specific manuscripts of the Vita Remigii proves that this text was not copied in the way the archbishop hoped it would be.

\footnotetext{
38 VR, c. 16, 306, 5-15: "Et ne quis etiam contra apostolum delectans vocum novitates dicere presumat, aut sacras regulas contra hoc misericordiae Domini exemplum constituisse, aut beatum Remigium divina preceptione in hoc opere contra sacras regulas de Genebaudo egisse, aut ipsum Genebaudum contra regularem constitutionem post lapsum in gradu mansisse, satisfaciat illi consona catholicorum patrum sententia: Ut, inquiens, constitueretur in aecclesia, ne quisquam post alicuius criminis penitentiam clericatum accipiat, vel ad clericatum redeat, vel in clericatu maneat, non desperatione indulgentiae, sed rigore factum est disciplinae. Alioquin contra claves datas aecclesiae disputabitur, de quibus dictum est: 'Quaecumque solveritis super terram, erunt soluta et in caelo'. In eo enim, quod dicitur: 'Quaecumque solveritis, erunt soluta,' nihil excipitur, nihil non comprehensum relinquitur.

39 VR c. 16, 306, 21-30 = Aug., Ep. n 185, § 10, in Augustin, Epistolae, ed. A.Goldbacher, CSEL 57, repr. New York, 1961, p. 39.

40 Hincmarus Remensis, Capitula 1-5, ed. R. Pokorny, M. Stratmann, MGH, Capit. episc. 2, 1995, p. 34-89, on pp. 6266,4 .
} 
At first sight, Hincmar's hopes would seem to have been fulfilled. After the death of Hincmar in 882, the Vita Remigii was often copied in Francia occidentalis, and, no surprise, especially in the province of Rheims. In fact it had an extraordinary dissemination, with manuscripts that are extremely numerous for a work of the ninth century: Krusch read 31 of them, but there are at least 85 . However, from these 31 , Krusch had to devise six categories to produce a coherent stemma, because the transmission of the text is highly volatile: there are only three almost full manuscripts and very few manuscripts are alike. The Vita Remigii is indeed a monument, a Vita so long that it was almost never thoroughly copied after the $11^{\text {th }}$ century. It is understandable that all its annexes -the prologue, table of contents, preface or reading guide, and documents such as the testament of Remigius- were omitted by scribes. But that is also true of the more biographical chapters, which are almost never copied verbatim. All copyists seem to have been puzzled by the heterogeneity of the work. They first removed the appendices. But they also cut pieces in narrative chapters, to rid the Vita of all speculative passages. Each manuscript of the Life of Saint Remigius therefore provides the chance to examine the shift between the enunciation of rules and their effectiveness. This is an ongoing problem in the study of medieval norms: we know what the rules say, but not if they were implemented. Starting from the consideration of a small part of the dissemination of Vita Remigii's manuscripts, we can actually assess whether the most normative passages of this text have been preserved, or not. Let us first recall the general structure of the Vita.

\begin{tabular}{|l|l|l|}
\hline BHL 7152 & Prologue & $\begin{array}{l}\text { Hincmar recounts the circumstances under which } \\
\text { he wrote the Vita and by what methods. }\end{array}$ \\
\hline BHL 7153 & Table of contents & $\begin{array}{l}\text { A very detailed table of chapters (summaries rather } \\
\text { than titles) }\end{array}$ \\
\hline BHL 7154 & Altera praefatio & A guide for the reading of the text \\
\hline BHL 7155 & Cap. 1-23 (Vita) & \\
\hline BHL 7156 & $\begin{array}{l}\text { Cap. 24-28 (Miracula } \\
\text { post mortem) }\end{array}$ & \\
\hline BHL 7157 & Cap. 29 (translatio 852) & \\
\hline BHL 7158 & Cap. 30 & Eulogy of Remigius: he equals all the other saints \\
\hline BHL 7159 & Cap. 31 & Another eulogy of Remigius \\
\hline BHL 7160 & Cap. 32 & Remigius' Testament \\
\hline BHL 7161 & Carmen 1 & Verses written on the saint's shrine by Hincmar \\
\hline BHL 7162 & Carmen 2 & Other verses written on the saint's shrine \\
\hline
\end{tabular}

Some faithful scribes kept all the prose and narrative chapters, as in the oldest manuscript, from Saint-Vaast and still in Arras today (Arras, BM 199 (189), from the very end of the $10^{\text {th }}$ century). It has been damaged, but once contained most of the Vita:

\begin{tabular}{|l|l|l|}
\hline BHL 7152 & Prologue & Now missing \\
\hline BHL 7153 & Table & Fol. 1-2v \\
\hline BHL 7154 & Altera praefatio & Fol. 3 \\
\hline BHL 7155 & Cap. 1-23 (Vita) & Fol. 3v-28. \\
\hline BHL 7156 & Cap. 24-28 (Miracula) & Fol. 28-31v, with an accidental omission \\
\hline BHL 7157 & Cap. 29 (translatio 852) & Fol. 31v \\
\hline BHL 7158 & Cap. 30 & Fol. 32 \\
\hline BHL 7159 & Cap. 31 & Fol. 33 \\
\hline BHL 7160 & Cap. 32 : testament & - \\
\hline BHL 7161 & Carmen 1 & - \\
\hline BHL 7162 & Carmen 2 & - \\
\hline
\end{tabular}


The text has been copied with infinite respect by several copyists, without missing a single line. There are even the signs in the margins that Hincmar provided to distinguish the more difficult passages that have to be pondered on, and the ones that everybody can listen to. ${ }^{41}$ However, did these indications, that make it so easy to identify the speculative moments of the Vita, help other scribes to write an expurgated text, simply showing them what they had to suppress? A careful reading of some abbreviated manuscripts actually shows that, though the scribes indeed did remove the more theoretical passages, they chose them themselves. For instance, in a manuscript now in Rouen (Rouen, BM 1381 (U67)), let us read the chapter 6 of the Vita. In this chapter, Hincmar tells how Remigius healed a man who was poor, blind and possessed; he concludes that Remigius, who can give a threefold remedy, manifests the Trinity. Then he underlines the necessity for a Christian to pray and beg constantly, to accord what he believes and what he practises, to obtain by prayer what is really good for him. In the edition of the text, two moments are clearly distinguished: first, the story of the healing ${ }^{42}$, second, Hincmar's meditation on the three evils that afflicted the man, reported in the margin by the Greek letter gamma. ${ }^{43}$ But the Rouen manuscript scribe failed to identify this organization. He kept the story and its conclusion about the Trinity, but only a part of the meditation that follows. ${ }^{44}$ We might suppose that the scribe simply interrupted his work when he thought that the anecdote of the miraculous healing was completed, rather than selecting the sentences according to a specific purpose.

Another manuscript, again now in Arras, presents a more interesting case, even if it is difficult to draw solid conclusions from a manuscript that has been damaged (Arras BM, ms 31 (0823), fol. 1632). The Vita Remigii copied here is an abbreviated version of the Hincmarian text. A brief look at chapter 16 about Genebaud gives a good idea of the proportions of this abbreviation: the scribe considered useless more than half of the text ${ }^{45}$, at first sight the most speculative passages, the dogmatic and exegetical teachings. However, not all the theoretical passages are omitted, so the selection does not refer to a more popular or a more liturgical use of the Vita, when shortened. The scribe omitted in fact all passages written in the first person plural ${ }^{46}$. Hincmar often uses this rhetorical formula, as if talking directly to the monks of Saint-Remi as their abbot, or to the clergy as their archbishop: "We read in the sacred history", "We have with Bishop Genebaud...", "We heard... ", "So, dearest brothers, we have... confidence in the mercy of our Creator", "Think about what we do, think again about what we did... ", etc. ${ }^{47}$ All these exhortations, which are brief and easy to understand, have been removed : so the abbreviation does not match, or not only, the desire to make the text more accessible for the simple. This abbreviation, stifling the voice of Hincmar and the historical context of the first enunciation of the Vita, is the price that was paid for the text to be more than a Rheims history for Rheims readers. As the manuscripts are shortened, the legend of Remigius becomes part of a national history that largely exceeded Hincmar's purpose, in which the memory of the baptism of Clovis becomes the essential moment of Remigius's career. The hagiography is still considered as a story that can teach something, but it is no longer a question of behaviour or of faith: out of Hincmar's hands, through the copy of scribes, hagiography now teaches the meaning of political history of the Frankish realm.

\footnotetext{
41 VR Altera praefatio, 258, 25-27: "I took care to distinguish the passages we must read to the people and those that should be kept for more educated and more studious readers.", "...quantum inde, populo audiente, legantur, et que instructioribus et studiosioribus, quando sibi licuerit vel libuerit, legenda serventur, designare curavi. "See the whole paragraph: VR 258, 15-259, 5.

42 VR, c. $6,271,38-272,12$.

43 VR, c. $6,272,13-273,14$.

44 He copies VR, c. 6, 271, 38-272, 16.

45 The scribe omitted VR, c. 16, 300, 25-301, 31 then VR 302, 32-303, 8 ; VR 304, 8-305, 3 and VR 305, 6-306, 30.

46 From VR 303, 5-8.

47 VR 304, 19 ; VR 304, 23 ; VR 304, 27 ; VR 304, 34-40. Perhaps these moments come directly from homilies that Hincmar really preached.
} 